\title{
THE MAXIMUM EXTENT OF GLACIERS IN PART OF WEST FALKLAND
}

\author{
By C. M. Clapperton and D. E. Sugden \\ (Department of Geography, University of Aberdeen, Aberdeen AB9 2UF, Scotland)
}

\begin{abstract}
Although it is known that cirque glaciers once existed in the Falkland Islands, it has remained in doubt whether or not the islands were ever covered by ice caps or an ice sheet during the Cainozoic. This paper scrutinizes geomorphological evidence on the south-eastern flank of a high massif in West Falkland. It is suggested that, at the time of their maximum extent in the Cainozoic, the largest glaciers were no more than $2.7 \mathrm{~km}$ long.

RÉsumé. L'extension maximum des glaciers dans une partie du West Falkland. Bien qu'il soit connu que des glaciers de cirque ont existé dans les Iles Falkland, on hésitait encore à affirmer que les îles avaient ou non été recouvertes par une calotte glaciaire au cours du cenozoïque. On passe au crible dans cet article les signes géomorphologiques sur le flanc Sud-Est d'un haut massif dans le West Falkland. On suggère qu'au moment de leur extension maximum au cenozoïque, les plus grands glaciers n'ont pas dépassé $2,7 \mathrm{~km}$ de longueur.

Zusammenfassung. Höchststand der Gletscher in einem Teil von West-Falkland. Obwohl bekannt ist, dass Kar-Gletscher früher auf den Falkland-Inseln vorhanden waren, blieb es zweifelhaft, ob die Inseln jemals während des Känozoikums von Eiskappen oder einer Eisdecke besetzt waren. Diese Arbeit prüft geomorphologische Hinweise an der Süd-Ost-Flanke eines hohen Massivs auf West-Falkland. Es lässt sich folgern, dass die grössten Gletscher während ihres Höchststandes im Cenozoikum nicht länger als $2,7 \mathrm{~km}$ waren.
\end{abstract}

Evidence that cirque glaciers existed in parts of the Falkland Islands during the Pleistocene was recently presented by Clapperton (I97 I), but it has remained in doubt whether or not the islands were ever covered by ice caps or an ice sheet. The writers recently had the opportunity to test this possibility in the vicinity of Port Howard, West Falkland, by investigating the landforms and superficial deposits of Double Stream Basin and adjacent valleys (Fig. I).

Double Stream Basin is a complex of broad valley heads cut into an unnamed mountain massif, the summits of which rise to over $680 \mathrm{~m}$. The massif, consisting mainly of quartzite rocks, is one of the highest and most extensive in West Falkland. In places the valley heads have been modified by the development of four prominent cirques, each with cliffed backwalls and rock-basin floors, and three less deeply excavated cirques (Fig. 2). The backwall of the deepest cirque is almost $200 \mathrm{~m}$ high.

\section{THE EXTENT OF GLACIERS}

Down-stream from the cirque basins the floor of Double Stream Basin is covered with a deposit of boulders and stones contained in a compacted matrix (Figs 2 and 3). From a maximum thickness of over $25 \mathrm{~m}$ near the cirques the deposit thins out down-valley and at an altitude of ${ }_{1} 65 \mathrm{~m}$ terminates at a point $2.7 \mathrm{~km}$ from the most distant cirque. Stone roundness tests using the method of Reichelt (I96I) showed that at one site $78 \%$ of included fragments are subangular and $28 \%$ angular and at another that $4 \%$ are sub-rounded, $60 \%$ are subangular and $36 \%$ are angular. Some of the stones are striated and polished. Mechanical analysis of the matrix revealed a bimodal grain-size distribution with a high proportion of medium to fine sand ( $5 \mathrm{I} \%$ between $\mathrm{I}$ and $3 \phi$ units) and pebbles $(24 \%$ between $-\mathrm{I}$ and -4 $\phi$ units). Such characteristics are typical of glacial deposits and this, together with the location of the deposit extending down-valley from glacial cirques, strongly suggests that the deposit is glacial till.

Down-valley from the till, the floor and lower slopes of the valley are mantled with solifluction deposits, such as boulder lobes and stone runs, and with alluvial fans at the confluence of tributary streams. There is no further evidence of till in any of the river-bank exposures along Double Stream valley, or indeed of any other feature directly related to 


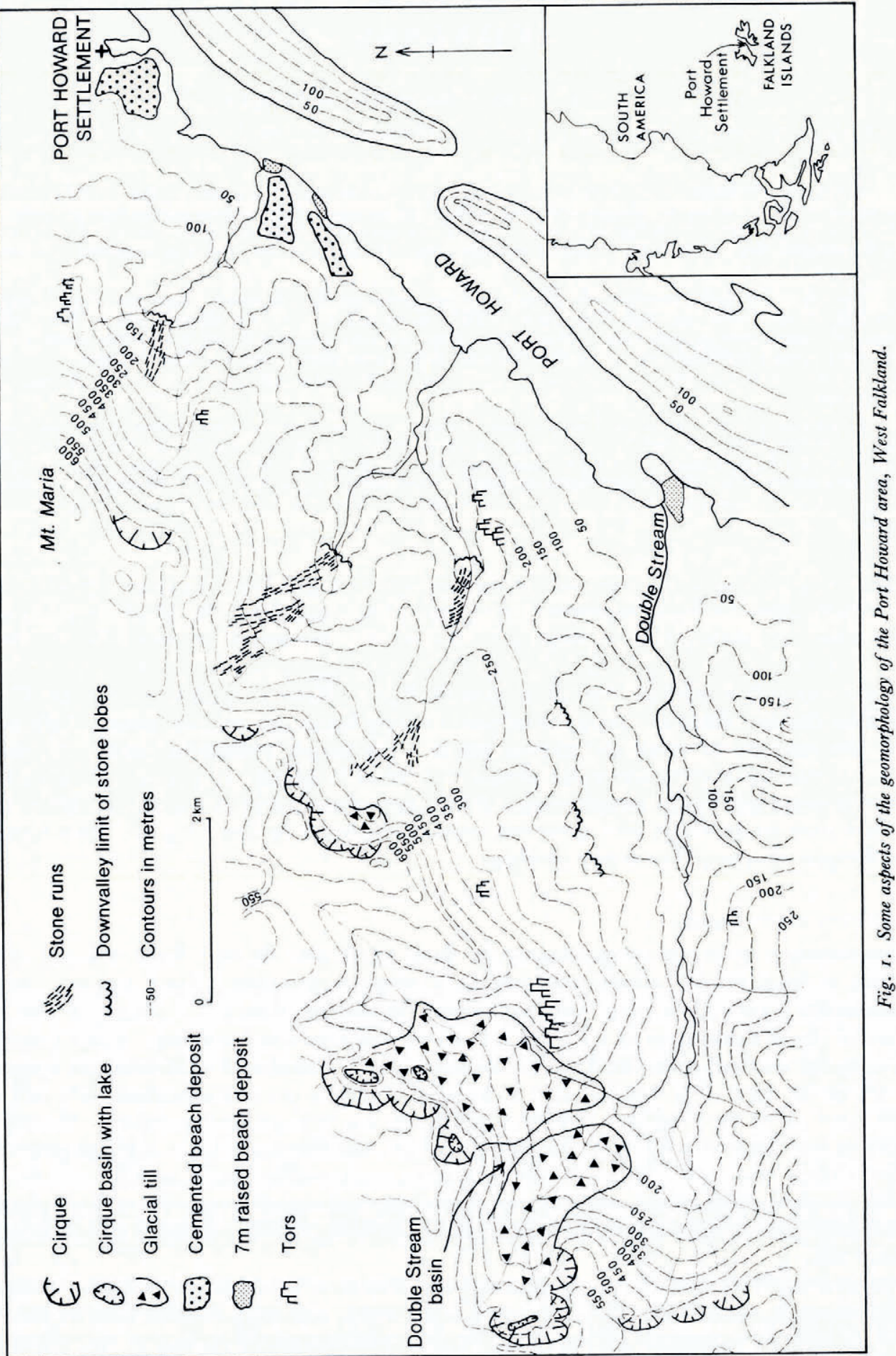




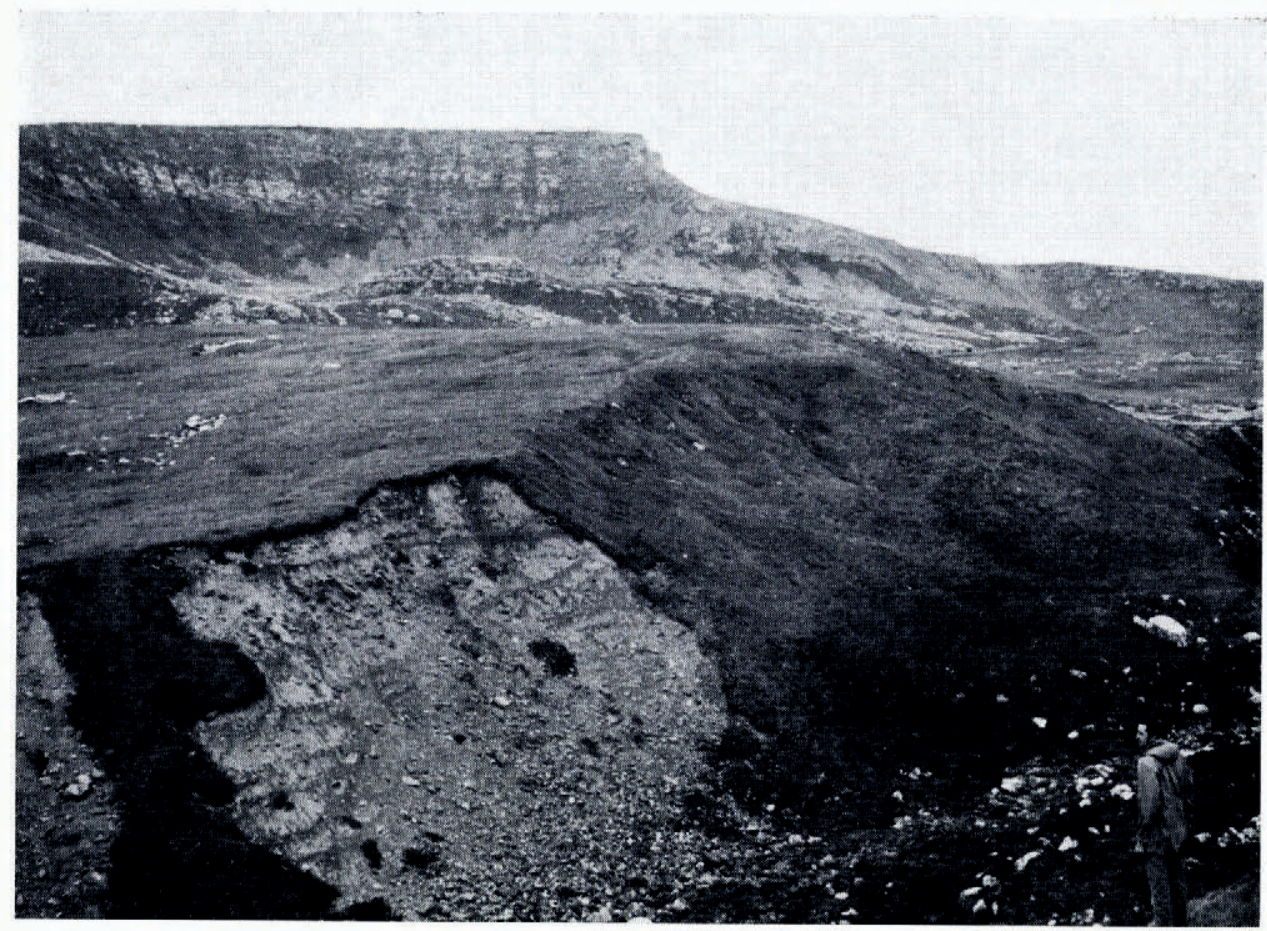

Fig. 2. A $25 \mathrm{~m}$ thick section in the till deposit at an altitude of c. $400 \mathrm{~m}$ in Double Stream Basin. The cliffs of one of the cirques can be seen in the background.

glacial action. It therefore seems from the available evidence that when glaciers were present in the Falkland Islands the two glaciers emanating from the cirque complex of Double Stream Basin were no more than $2.5 \mathrm{~km}$ and $2.7 \mathrm{~km}$ in length, respectively.

Small cirques also lie at the heads of other valleys draining into Port Howard from the same mountain massif, but they do not contain comparable till deposits. The valley floors immediately down-valley of the cirques are covered with a deposit, consisting of stone runs and stone lobes, which terminates abruptly at an altitude of $100-135 \mathrm{~m}$. Although the significance of this altitudinal limit is difficult to evaluate without wider studies, it is possible that part of the deposit represents till which has been subsequently modified by solifluction. Under such circumstances, it is difficult to fix the down-valley limits of glaciers in this part of the massif. However, it can be suggested that they were restricted either to the cirques themselves or to the upper reaches of the valleys.

\section{THE PROBLEMS OF RAISED BEAGHES}

When assessing the extent of glaciation in West Falkland, it is important to consider the raised beach deposits which, for example, occur between Port Howard settlement and Double Stream Basin, because such deposits might relate to glacio-isostasy. There are two distinct beach deposits (Fig. I). A lower beach composed of loose platy pebbles, similar in shape to pebbles on the present beach, occurs as a terrace feature $7 \mathrm{~m}$ above high-water mark at three localities (Fig. 4). The upper beach deposit is cemented and at two sea-cliff sites it consists of rounded and sub-rounded pebbles and cobbles overlying shaly bedrock. The upper beach also crops out on the surface of degraded terraces that terminate inland at $c .45 \mathrm{~m}$. Mechanical 


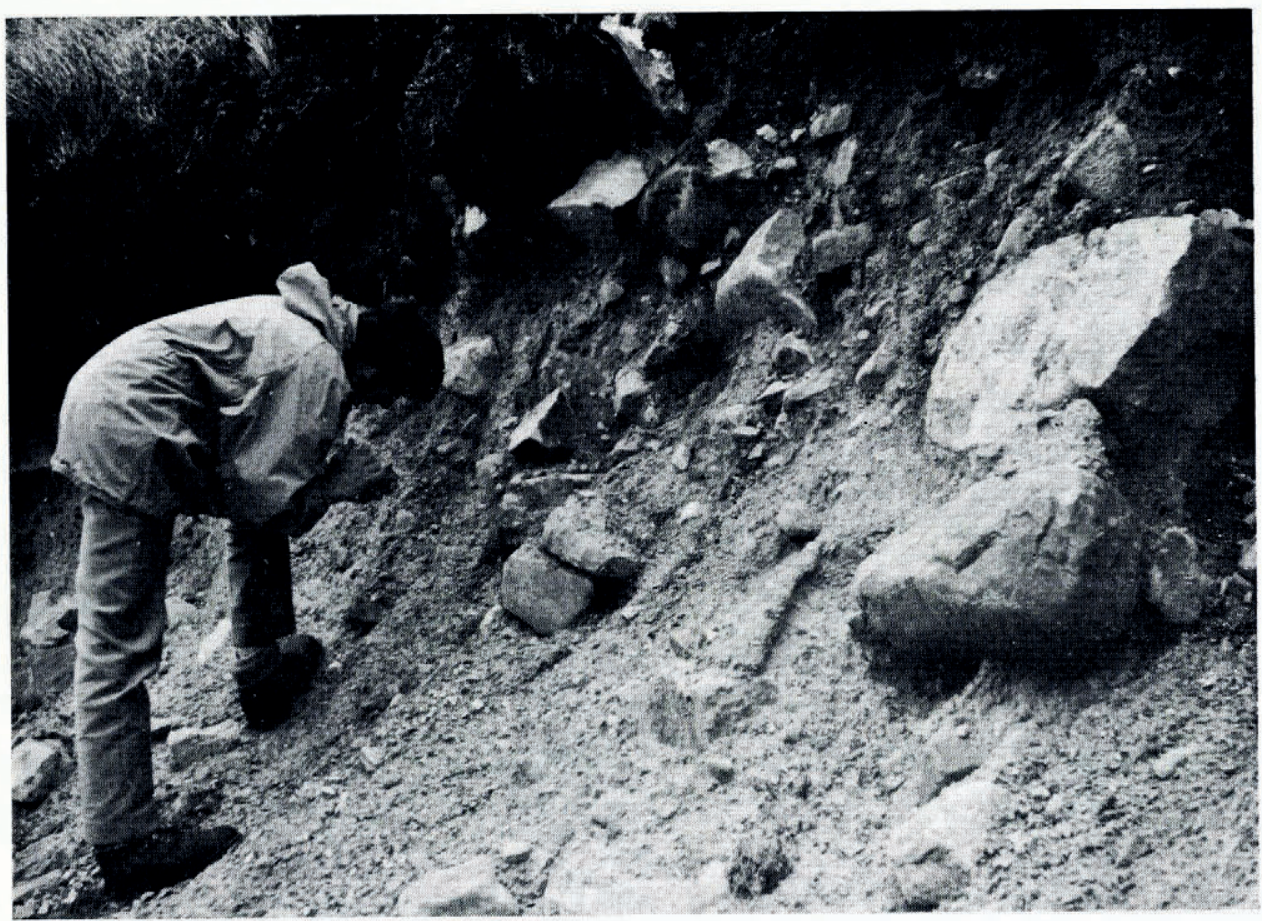

Fig. 3. Detail of the till deposit at an altitude of $200 \mathrm{~m}$ in Double Stream Basin. Some of the stones are striated.

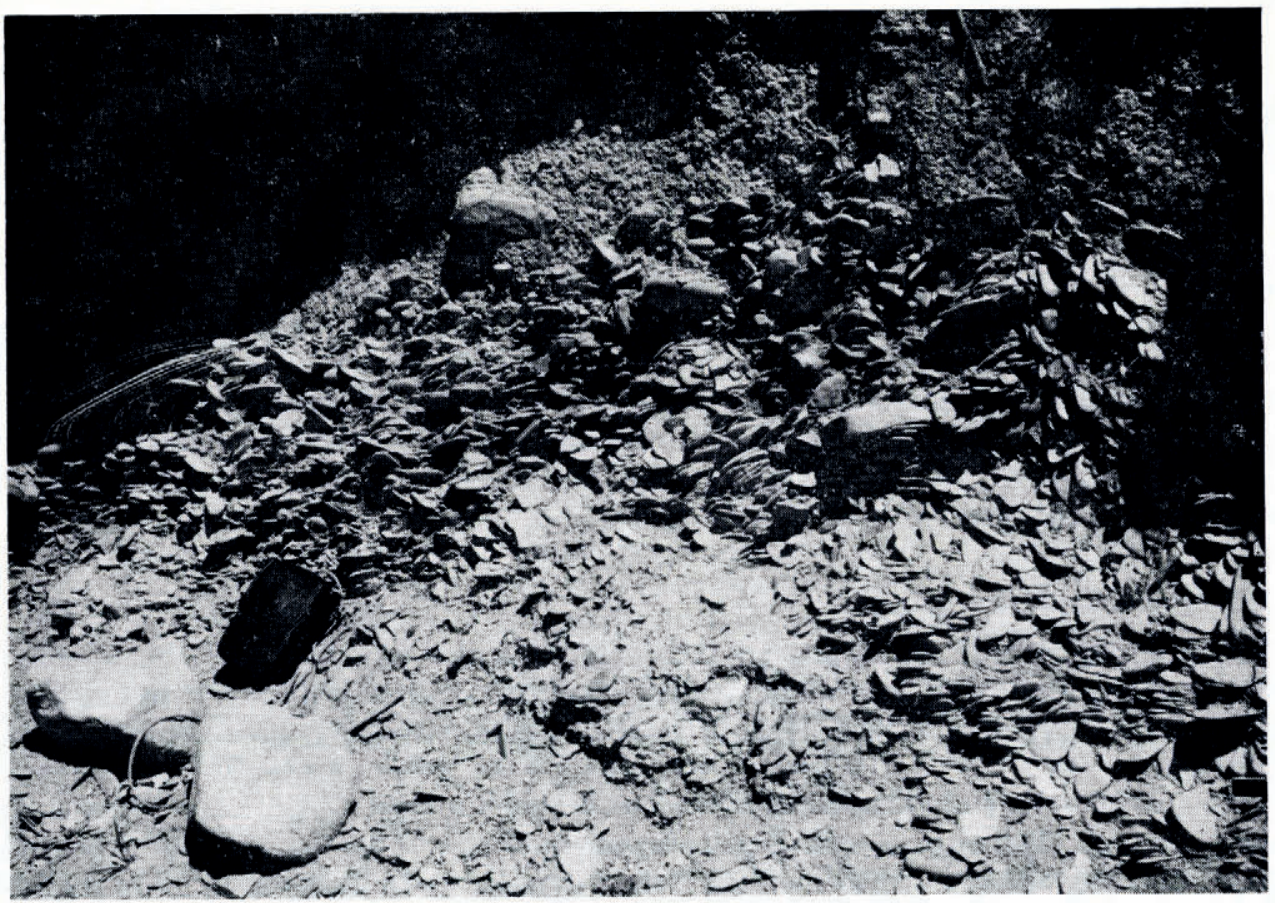

Fig. 4. Detail of the $7 \mathrm{~m}$ raiset beach deposit as exposed on the shore of Port Howard. 
analysis of the matrix of this latter deposit revealed that it consists mainly of coarse and medium sand $(56 \%$ between $o$ and $\mathrm{I} \phi$ units $)$ and that it is relatively well-sorted.

Adie (1953) described beach deposits at about $7 \mathrm{~m}$ in East Falkland, a level with which Greenway (1972) has recently correlated river terraces, while Andersson (1907) observed beach shingle deposits up to an altitude of $69 \mathrm{~m}$ at Cape Meredith (West Falkland). Thus it is possible that beach deposits representing former high sea-levels may be quite widespread in the Falkland Islands. In the absence of fossils and datable organic material in these deposits, it is difficult to assign an age to them and to assess their significance in relation to the glaciation of the Falkland Islands. If the upper deposit is glacio-isostatic in origin, its altitude implies the former presence of an extensive ice cap for which no other field evidence has yet been found. It is perhaps more likely that the Falkland Islands block is structurally linked with adjacent Patagonia, where tectonic uplift in the late Tertiary has produced prominent raised marine deposits along the Atlantic seaboard, and that the upper beach of Port Howard is of a similar origin.

If the lower deposit is glacio-isostatic in origin, its altitude implies the former presence of a small ice cap or series of ice caps that depressed East and West Falkland. The possibility that the high mountain massifs in West Falkland formerly supported ice caps was suggested from the interpretation of valley forms on air photographs by Clapperton ( I 97 I), but definite field evidence has yet to be found. The extent of till in Double Stream Basin certainly does not support the contention that an ice cap covered the area. An alternative explanation of the $7 \mathrm{~m}$ beach is that it relates to the Eemian (Sangamon) interglacial when eustatic sea-level may have been a few metres higher than at present as a consequence of the collapse of the west Antarctic ice sheet (Mercer, r968; John, I972).

Unless the raised beaches are later shown to be related to glacio-isostatic movements within the Falkland Islands, it is reasonable to conclude that, at the time of the maximum extent of glaciers in West Falkland, ice did not extend beyond the cirques and the upper reaches of associated valleys.

\section{Acknowledgements}

We would like to thank the British Antarctic Survey, the Carnegie Trust for the Universities of Scotland and the Trans-Antarctic Association for support. Also we are indebted to Mr and Mrs D. Pole-Evans of Port Howard for generous camp support.

M.S. received I5 Fuly 1975

\section{REFERENCES}

Adie, R. J. 1953. New evidence of sea-level changes in the Falkland Islands. Falkland Islands Dependencies Survey. Scientific Reports, No. 9.

Andersson, J. G. 1907. Contributions to the geology of the Falkland Islands. Wissenschaftliche Ergebnisse der Schwedischen Südpolarexpedition, 1901-1903, Bd. 3, Lief. 2.

Clapperton, C. M. 1971. Evidence of cirque glaciation in the Falkland Islands. Fournal of Glaciology, Vol. 10, No. 58 , D. $12 \mathrm{I}-25$.

Greenway, M. E. 1972. The geology of the Falkland Islands. British Antarctic Survey. Scientific Reports, No. 76.

John, B. S. 1972. Evidence from the South Shetland Islands towards a glacial history of west Antarctica. (In Price, R. J., and Sugden, D. E., comp. Polar geomorphology. London, Institute of British Geographers, p. 75-92. (Institute of British Geographers. Special Publication No. 4.))

Mercer, J. H. 1968. Antarctic ice and Sangamon sea level. Union de Géodésie et Géophysique Internationale. Association Internationale d'Hydrologie Scientifique. Assemblée générale de Berne, 25 sept.-7 oct. 1967. [Commission de Neiges et Glaces.] Rapports et discussions, p. 2 I 7-25.

Reichelt, L. I961. Über Schotterformen und Rundungsgradanalyse als Feldmethode. Petermanns Geographische Mitteilungen, 105. Jahrg., I. Quartalsht., p. $15^{-24}$. 